\title{
Study of factors affecting the incidence of skin cancer in patients after liver transplant ${ }^{*}$
}

\author{
Gabriela Rached Campos ${ }^{1}$ \\ Ivan Dias de Campos Junior ${ }^{1}$
}

\author{
Ilka de Fátima Santana Ferreira Boin² \\ Maria Letícia Cintra ${ }^{3}$
}

DOI: http:/ / dx.doi.org/10.1590/abd1806-4841.20175946

Abstract: BACKGROUND: Many factors are currently being identified as potential inductors of skin cancer in patients after a liver
transplant, among them, immunosuppressive regimen.
OBJECTIVE: To study the factors that influence the incidence of skin cancer in patients after liver transplant.
METHODS: We have carried out a retrospective and observational study with 170 transplanted patients who had undergone
transplantation from 1997 to 2010 . We have adjusted the multiple logistic regression model (saturated model) to the ensemble
of collected data using skin cancer as dependent variable, indicated in anatomopathological analysis between 1997 and 2014 .
RESUlTs: Incidence of skin cancer was $9.4 \%$. Predictors were incidence of diabetes in the third year after the transplantation
( $\mathrm{p}=0.047)$, not using tacrolimus in the first year after the transplantation ( $\mathrm{p}=0.025$ ) and actinic keratosis ( $\mathrm{p}=0.003$ ).
STUDY LiMITATIONS: An important limitation is that the interpretation of the results was based on information collected of pa-
tients undergoing transplantation at a single center. Future research, multicentric and involving larger and more diverse
populations, are needed.
ConCLUSIONS: Factors found might contribute to Brazilian surveillance programs associated with decreased incidence of skin cancer. Keywords: Immunosuppressive agents; Liver transplant; Skin neoplasms; Transplantation

\section{INTRODUCTION}

The performance of organ transplants is a very important achievement in the health system, being a safe and effective therapeutic alternative in the treatment of several diseases. ${ }^{1}$

It is a fact that much of the progress in liver transplant is due to the development of immunosuppressive regimens. However, high doses of these drugs and their prolonged use imply toxicity. Thus, Medicine began to experience the increase of diseases in immunodeficient organisms, such as pharmacodermia, infections, photosensitivity, malignant and pre-malignant tumors, as well as transplantation typical diseases, such as graft-versus-host disease. ${ }^{1}$

As is the case in the general population, carcinoma is the most common malignant tumor, as well as the greatest cause of morbidity among post-transplant patients.,3

Incidence of skin cancer is increasing rapidly in several countries. However, there are estimates that worldwide, $45 \%$ of preventable carcinomas are cutaneous. ${ }^{4}$
Overall, it is believed that $90 \%$ of non-melanoma skin cancers and $65 \%$ of melanomas can be attributed to sun exposure. Non-melanoma skin cancer is more associated with cumulative solar action, while melanoma, with intense episodes of acute sun exposure, resulting in sunburn. ${ }^{5}$

Non-melanoma skin cancer accounts for more than $90 \%$ of post-transplant skin cancers. In contrast to general population, transplant recipients develop squamous cell carcinoma (SCC) more often than basal cell carcinoma (BCC). ${ }^{6,7}$ Thus, SCC can occur 65 to 250 times more frequently in transplanted patients than in the general population, whereas BCC occurs 10 to 20 times more frequently. Lesions appear, on average, two to four years after transplantation and increase in frequency over time. This is particularly important because, in addition to SCC being more aggressive than BCC, it has a tendency to recur, particularly in immunocompromised patients. ${ }^{10}$

Incidence of Non-melanoma skin cancer in liver, kidney and heart transplant recipients ranges from $1.5 \%$ to $22 \%, 2 \%$ to $24 \%$,

Received on 18.04.2016

Approved by the Advisory Board and accepted for publication on 10.12.2016

* Study conducted at Hepatic Transplant Unit of Clinics Hospital of School of Medical Sciences of Universidade Estadual de Campinas (FCM-Unicamp) Campinas (SP), Brazil.

Financial support: Coordination for the Improvement of Higher Education Personnel.

Conflict of interest: None.

Post-Graduation Program in Surgery Sciences of School of Medical Sciences of Universidade Estadual de Campinas (FCM-Unicamp) - Campinas (SP), Brazil. Department of Surgery of School of Medical Sciences of Universidade Estadual de Campinas (FCM-Unicamp) - Campinas (SP), Brazil.

Department of Pathologic Anatomy of School of Medical Sciences of Universidade Estadual de Campinas (FCM-Unicamp) - Campinas (SP), Brazil.

(C2017 by Anais Brasileiros de Dermatologia 
and from $6 \%$ to $34 \%$, respectively, within five years of transplant, depending on geographic location and other factors. ${ }^{10}$

Malignant cutaneous neoplasms are well-known complications after organ transplantation; however the risk factors associated with its development are still not well defined in post-liver transplant patients.

\section{METHODS}

This is a retrospective observational study performed in a single center, with liver transplant patients at the Liver Transplant Unit of the Clinics Hospital of the School of Medical Sciences (FCM) of the Universidade Estadual de Campinas (Unicamp), Campinas, SP, Brazil, from March 1997 to December 2010.

Patients presenting survival lower than three years after transplantation or who had incomplete data in the study protocol or who used an immunosuppressive regimen other than tacrolimus and cyclosporine were excluded from the study.

The study included adult patients ( $>18$ years), regardless of race or sex, submitted to liver transplant, from cadaveric donors, by the piggy-back preservation technique, with survival greater than or equal to three years after transplantation and on the use of tacrolimus or cyclosporine.

Preoperative variables were: sex $(\mathrm{M} / \mathrm{F})$, age, body mass index $\left(\mathrm{kg} / \mathrm{m}^{2}\right)$, glycemia $(\mathrm{mg} / \mathrm{dL})$, baseline diseases (hepatitis $\mathrm{C}$ [HCV], alcoholic cirrhosis [ALC] and hepatocellular carcinoma $[\mathrm{HCC}]$ ), date of surgery and scores: MELD (Model for End-Stage Liver Disease) and BAR (Balance of Risk).

Post-operative variables were: use of tacrolimus and/or cyclosporine, glycemia $(\mathrm{mg} / \mathrm{dL})$, glomerular filtration estimation by the Cockcroft-Gault equation ( $\mathrm{ml} / \mathrm{min})$, smoking history, skin cancers and previously selected actinic keratoses with suspected SCC that led to referrals to specialists and were biopsied.

All data from the postoperative variables were collected at the first patient return visit after the first and third years of the operation, with the exception of skin cancers and actinic keratoses with suspected SCC. These were collected from the anatomopathological reports between 1997 and 2014, stored in the computerized database of the Department of Pathological Anatomy of the Clinics Hospital, School of Medical Sciences (FCM). The slides were revised to confirm the morphological diagnosis and to assess the degree of degeneration of the elastic fibers of the dermis adjacent to the neoplasia.

SCCs were classified according to the invasion (in microinvasive, superficial and frankly invasive) and by the degree of differentiation (in well, moderately and poorly differentiated), which is based on four criteria, namely cytological atypia, mitotic activity, intercellular bridges and cornification, as described by Broders. ${ }^{11}$ BCCs were classified according to their predominant pattern of histological growth in: nodular, superficial, sclerosing, micronodular and sclerodermiform, being the first two of indolent biological behavior and the last three, aggressive local. Malignant melanoma cancers (MMC) were classified by level of microanatomic invasion of the neoplasm (Clark levels I, II, III, IV and V).

The BAR score was calculated for each patient according to the formula available at http:/ / www.assessurgery.com/bar-score/ bar-score-calculator/. In this score, the variables used were: donor age (years), cold ischemia time (hour), retransplantation (yes/no), ICU days with artificial life support (mechanical ventilator), recipient age (years), and pure MELD value with no special points.

A multiple logistic regression model (saturated model) was adjusted to the collected data set, with a variable response to skin cancer after transplantation indicated in anatomopathological analysis between 1997 and 2014. For the factors studied, the respective odds ratios (OR) were obtained, as well as their $95 \%$ confidence intervals, $\mathrm{p}$ values, significance of $5 \%$, and descriptive analysis. SAS System for Windows (Statistical Analysis System), version 9.4 was used (SAS Institute Inc, 2002-2012, Cary, NC, USA).

\section{RESULTS}

Of the 349 liver transplant recipients, 179 were excluded (155 with survival < 3 years after transplantation and 24 with incomplete data or who used another drug in the immunosuppressive regimen rather than tacrolimus and cyclosporine). The study included 170 patients.

Sixteen $(9.4 \%)$ patients in the study group $(n=170)$ presented skin cancer after liver transplantation, according to anatomopathological analysis from 1997 to 2014. Seven patients had only one skin cancer and nine patients had more than one skin cancer, totaling 30 cutaneous neoplasias (Table 1). Seven patients had previously selected actinic keratoses, with suspected epidermoid carcinoma.

Among the 30 skin cancers found, 22 were SCCs, and according to the degree of differentiation, one was poorly differentiated, six were well differentiated and 15 were moderately differentiated (Figure 1). According to the degree of invasion, eight were frankly invasive, one was microinvasive and 13, were superficial. All BCCs were nodular. Two patients developed CMM, one being Clark I and the other Clark IV (Table 1). No specimen had, in the adjacent or underlying dermis, grade I elastosis; eight presented grade II elastosis; 11, grade III; and in the other 11 slides, it was not possible to evaluate the degree of elastosis.

There was a high prevalence of male patients $(72.4 \%)$ and mean age of 47.5 years (standard deviation \pm 11.2 years) at the time of transplantation.

Regarding race, 16/170 patients were brown, 1/170 was black and 153/170 were white.

Patients studied had a mean MELD score of 19.16 (standard deviation \pm 6.3 ) and a mean BAR score of 6.9 (standard deviation \pm 3.6 ).

$\mathrm{C}$ virus hepatitis was the cause for more frequent transplantation followed by alcoholic cirrhosis and hepatocellular carcinoma (Table 2).

In the first year after transplantation, the most commonly used immunosuppressant in the study population was tacrolimus, the drug of choice in $65.9 \%$ of patients. In the period between the first and third years, $13.5 \%$ of the patients received tacrolimus and cyclosporine at different periods, and $20.6 \%$ received only cyclosporine.

Regarding gender, of the 16 patients who developed skin cancer, $81.2 \%$ (13/16) were men and $18.7 \%$ (3/16), women; in relation to the underlying liver disease, $62.5 \%(10 / 16)$ had hepatitis C virus, $18.7 \%$ (3/16) had cirrhosis of the liver and 25\% (4/16) had hepatocellular carcinoma; regarding glycemia in the third year, $25 \%$ $(4 / 16)$ presented diabetes; in relation to smoking, $75 \%(12 / 16)$ had 


\begin{tabular}{|c|c|c|c|c|c|c|c|c|c|c|}
\hline \multirow[t]{3}{*}{ Patient } & \multicolumn{6}{|c|}{ Epidermoid Carcinoma } & \multirow{3}{*}{$\begin{array}{c}\text { Basal cell carcinoma } \\
\text { Nodular }\end{array}$} & \multirow{2}{*}{\multicolumn{2}{|c|}{ Melanoma }} & \multirow{3}{*}{$\mathbf{N}$ of lesions } \\
\hline & \multicolumn{3}{|c|}{ Degree of Differentiation } & \multicolumn{3}{|c|}{ Degree of Invasion } & & & & \\
\hline & M & $\mathrm{P}$ & $\mathrm{B}$ & $\mathrm{F}$ & MI & $\mathrm{S}$ & & Clark I & Clark IV & \\
\hline 1 & & $x$ & & $x$ & & & & & & 1 \\
\hline 2 & $x$ & & $x$ & & $x$ & $x$ & $x$ & & & 3 \\
\hline 3 & $x X$ & & & & & $X X$ & & & & 2 \\
\hline 4 & $x$ & & & & & $X$ & & & & 1 \\
\hline 5 & $X X$ & & & $x$ & & $x$ & & & & 2 \\
\hline 6 & $x$ & & $x$ & $x$ & & $X$ & & & & 2 \\
\hline 7 & $X X$ & & $x x$ & $X X X$ & & $x$ & $x$ & & & 5 \\
\hline 8 & $\mathrm{X}$ & & $x$ & & & $X X$ & & & & 2 \\
\hline 9 & & & $x$ & $x$ & & & & & & 1 \\
\hline 10 & $x X$ & & & & & $X X$ & & & & 2 \\
\hline 11 & $X$ & & & & & $x$ & & & & 1 \\
\hline 12 & & & & & & & $x$ & & & 1 \\
\hline 13 & $x$ & & & & & $X$ & & & & 1 \\
\hline 14 & $x$ & & & $x$ & & & $X X$ & & & 3 \\
\hline 15 & & & & & & & & & $X$ & 1 \\
\hline 16 & & & & & & & $x$ & $x$ & & 2 \\
\hline Total subtype & 15 & 1 & 6 & 8 & 1 & 13 & 6 & 1 & 1 & - \\
\hline Total type & 22 & 6 & 2 & 30 & & & & & & \\
\hline
\end{tabular}

Degree of Differentiation: $\mathbf{M}=$ Moderately; $\mathbf{P}=$ Poor; $\mathbf{B}=$ Well. Degree of Invasion: $\mathbf{F}=$ Frankly; $\mathbf{M I}=$ Microinvasive; $\mathbf{S}=$ Superficial. Number of lesions: $\mathbf{X}=1$ lesion; $\mathbf{X X =} 2$ lesions; $\mathbf{X X X =} 3$ lesions. $\mathbf{N}=$ Number
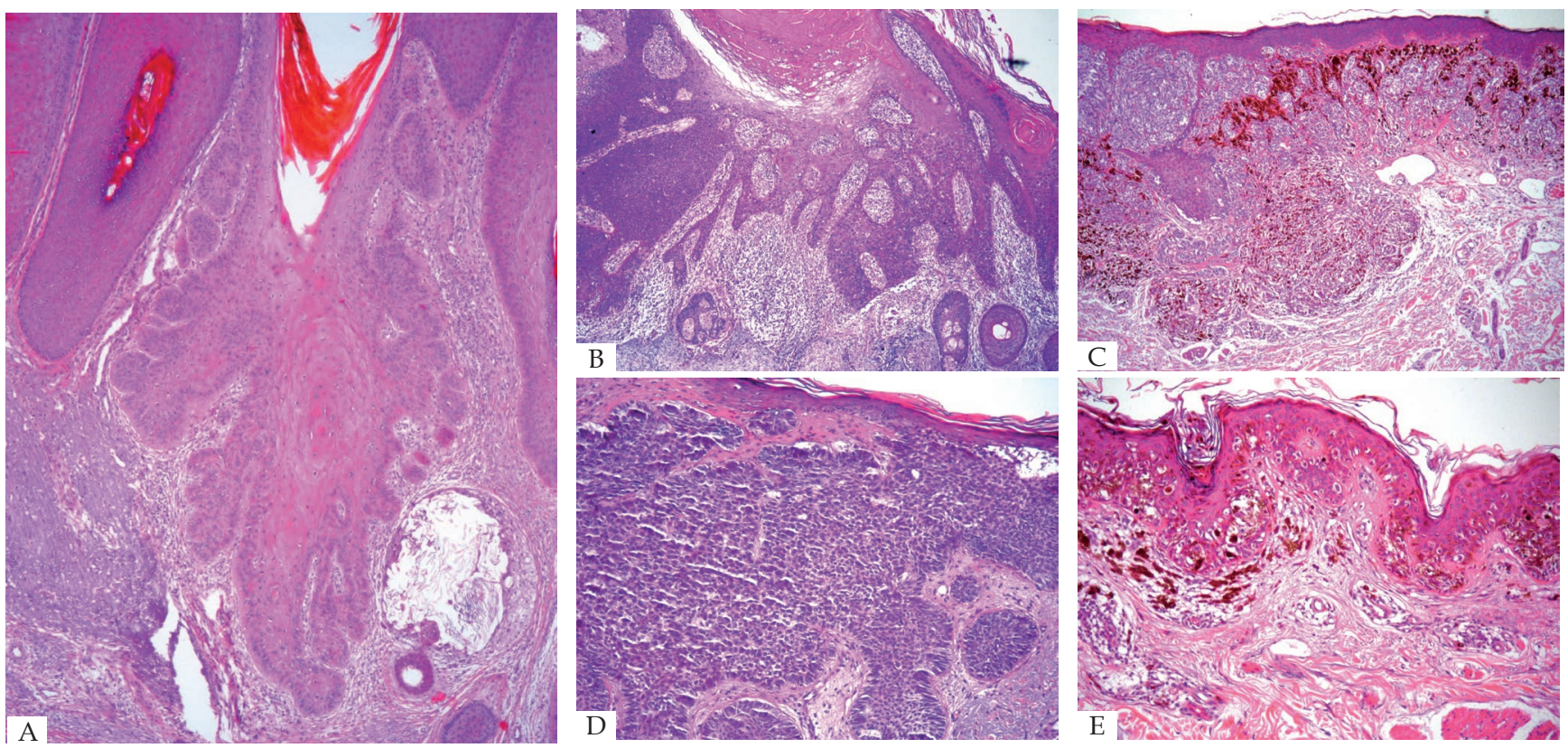

Figure 1: Microscopic analysis. A) Well-differentiated epidermoid carcinoma, invading the dermis (Patient \#9, Hematoxylin \& eosin, original magnification X40). B) Moderately differentiated epidermoid carcinoma, invading the dermis (Patient \#14, Hematoxylin \& eosin, original magnification X40). C) Malignant melanoma in vertical growth phase - microanatomic Clark level IV (Patient \#15; Hematoxylin \& eosin, original magnification X40). D) Nodular basal cell carcinoma (Patient \#14; Hematoxylin \& eosin, original magnification X100). E) In situ malignant melanoma - microanatomic Clark level I (Patient \#16; Hematoxylin \& eosin, original magnification X100) 
a history of smoking or were smokers. Mean number of years from transplantation to the onset of the first skin cancer was 5.4 years.

For the population studied, the significant factors for skin cancer were: presence of diabetes in the third year post-transplantation $(\mathrm{OR}=6.744 ; 95 \% \mathrm{CI}=1.021-44.547 ; \mathrm{p}=0.047)$, not using tacrolimus in the first year after transplantation $(\mathrm{OR}=22,300,95 \% \mathrm{CI}=$ 2,870-173,271, $\mathrm{p}=0.003$ ) and presented with actinic keratosis biop- sied on suspicion of epidermoid carcinoma $(\mathrm{OR}=22,300,95 \% \mathrm{CI}=$ 2,870-173,271; $p=0,003)$.

Although not statistically significant, patients who presented alcoholic cirrhosis at the time of the operation $(p=0.075)$ and those who smoked or had a history of smoking $(p=0.098)$ showed a tendency to develop skin cancer.

These data can be observed in table 3 .

\begin{tabular}{|c|c|c|c|}
\hline \multicolumn{2}{|l|}{ Characteristics } & $\mathbf{N}$ & $\%$ \\
\hline \multicolumn{4}{|c|}{ Preoperative variables } \\
\hline \multirow[t]{2}{*}{ Pure MELD } & $<20$ & 94 & 55.3 \\
\hline & $\geq 20$ & 76 & 44.7 \\
\hline \multirow[t]{2}{*}{ BAR } & $<9$ & 138 & 81.2 \\
\hline & $\geq 9$ & 32 & 18.8 \\
\hline Age in years in the date of $\mathrm{Tx}$ (mean. \pm standard deviation) & $47.5 \pm 11.2$ & - & - \\
\hline \multirow{2}{*}{ Sex } & Women & 47 & 27.6 \\
\hline & Men & 123 & 72.4 \\
\hline \multirow[t]{2}{*}{ BMI $(\mathrm{kg} / \mathrm{m} 2)$} & $<30$ & 148 & 87.1 \\
\hline & $\geq 30$ & 22 & 12.9 \\
\hline \multirow[t]{2}{*}{ Hepatitis C Virus } & No & 75 & 44.1 \\
\hline & Yes & 95 & 55.9 \\
\hline \multirow[t]{2}{*}{ Alcoholic cirrhosis } & No & 114 & 67.1 \\
\hline & Yes & 56 & 32.9 \\
\hline \multirow[t]{2}{*}{ Hepatocellular carcinoma } & No & 148 & 87.1 \\
\hline & Yes & 22 & 12.9 \\
\hline \multirow[t]{2}{*}{ Glycemia (mg/dL) } & $<126$ & 146 & 85.9 \\
\hline & $\geq 126$ & 24 & 14.1 \\
\hline \multicolumn{4}{|c|}{ Postoperative variables } \\
\hline \multirow[t]{2}{*}{ Glomerular Filtration 1st year (ml/min) } & $>60$ & 137 & 80.6 \\
\hline & $\leq 60$ & 33 & 19.4 \\
\hline \multirow[t]{2}{*}{ Glomerular Filtration 3rd year (ml/min) } & $>60$ & 132 & 77.6 \\
\hline & $\leq 60$ & 38 & 22.4 \\
\hline \multirow[t]{2}{*}{ Glycemia 1st year (mg/dL) } & $<126$ & 157 & 92.4 \\
\hline & $\geq 126$ & 13 & 7.6 \\
\hline \multirow[t]{2}{*}{ Glycemia 3rd year (mg/dL) } & $<126$ & 149 & 87.6 \\
\hline & $\geq 126$ & 21 & 12.4 \\
\hline \multirow[t]{2}{*}{ Tacrolimus 1st year } & No & 58 & 34.1 \\
\hline & Yes & 112 & 65.9 \\
\hline \multirow[t]{2}{*}{ Tacrolimus and Cyclosporine } & No & 147 & 86.5 \\
\hline & Yes (Distinct Periods) & 23 & 13.5 \\
\hline \multirow[t]{2}{*}{ Smoking } & No & 80 & 47.1 \\
\hline & Yes & 90 & 52.9 \\
\hline \multirow[t]{2}{*}{ Keratosis } & No & 163 & 95.9 \\
\hline & Yes & 7 & 4.1 \\
\hline \multirow[t]{2}{*}{ Skin cancer } & No & 154 & 90.6 \\
\hline & Yes & 16 & 9.4 \\
\hline
\end{tabular}

$\mathbf{B M I}=$ Body Mass Index. $\mathbf{B A R}=$ Balance of risk 
TABLE 3: Analysis of the associated factors of skin lesions in liver transplant patients after multiple logistic regression

\begin{tabular}{|c|c|c|c|c|c|}
\hline Variable & Category & $\mathbf{P}$ & OR & \multicolumn{2}{|c|}{$95 \% \mathrm{CI}$} \\
\hline Sex & Men/Women & 0.885 & 1.130 & 0.216 & 5.904 \\
\hline Age_OP & - & 0.473 & 1.031 & 0.949 & 1.120 \\
\hline BMI TX $\geq 30$ & Yes/ No & 0.764 & 1.444 & 0.131 & 15.935 \\
\hline Hepatitis C Virus & No/Yes & 0.279 & 2.223 & 0.522 & 9.473 \\
\hline Alcoholic cirrhosis & No/ Yes & 0.075 & 5.015 & 0.847 & 29.710 \\
\hline Hepatocellular carcinoma & Yes/ No & 0.667 & 1.479 & 0.249 & 8. 804 \\
\hline Pure MELD $\geq 20$ & No/ Yes & 0.832 & 1.186 & 0.243 & 5.791 \\
\hline $\mathrm{BAR} \geq 9$ & No/ Yes & 0.222 & 6.113 & 0.333 & 112.339 \\
\hline Glycemia operation & Yes/ No & 0.261 & 2.917 & 0.450 & 18.901 \\
\hline IRenal $1^{\text {st }}$ year & Yes/ No & 0.364 & 3.327 & 0.248 & 44.638 \\
\hline IRenal $3^{\text {rd }}$ year & No/ Yes & 0.334 & 3.547 & 0.271 & 46.392 \\
\hline Diabetes $1^{\text {st }}$ year & No/ Yes & 0.433 & 2.821 & 0.211 & 37.706 \\
\hline Diabetes $3^{\text {rd }}$ year & Yes/ No & 0.047 & 6.744 & 1.021 & 44.547 \\
\hline FK $1^{\text {st }}$ year & No/ Yes & 0.025 & 5.316 & 1.226 & 23.051 \\
\hline FK and $C y 3^{\text {rd }}$ year & No/ Yes & 0.591 & 1.736 & 0.231 & 13.042 \\
\hline Smoking & Yes/ No & 0.098 & 3.719 & 0.784 & 17.652 \\
\hline Keratosis & Yes/ No & 0.003 & 22.300 & 2.870 & 173.271 \\
\hline
\end{tabular}

MELD= Model for End-Stage Liver Disease; IRenal= Renal insufficiency; FK=Tacrolimus; $\mathbf{C y}=$ Cyclosporine; TX=Transplant; Age_OP=Age in operation

\section{DISCUSSION}

Several studies evaluate the risk factors and the pathophysiology of skin cancer in patients undergoing organ transplant, and the results are variable in the literature. ${ }^{10,12}$

In the studied population, incidence of skin cancer was $9.4 \%$ of the cases $(n=16)$; of these, $87.5 \%(14 / 16)$ of the patients had non-melanoma skin cancer; $6.25 \%$ (1/16), malignant melanoma; and $6.25 \%(1 / 16)$, BCC concomitant with CMM.

Incidence of skin cancer found in the study population was within the range described in the literature for individuals treated with liver transplantation (1.5\% to $22 \%) .{ }^{10,12}$ A study by Mithoefer et al. ${ }^{2}$ in the USA, with 151 liver transplant recipients and a mean follow-up of four years, showed a cumulative incidence of non-melanoma skin cancer of $22 \%$ in all patients. However, a study conducted by Jonas et al., in Germany, with 458 patients, found a cumulative incidence of skin cancer of only $1.5 \%$ after a follow-up with duration similar to that of other authors. ${ }^{13}$

Regarding solar elastosis, the majority had marked elastosis, showing the participation of photodamage as a cocarcinogen in post-transplantation cancers.

Clinical use of tacrolimus is increasing, and the drug is currently the based on more than $80 \%$ of liver transplants and $30 \%$ of kidney transplants. ${ }^{3}$ In the first year after transplantation, this immunosuppressant was used in $65.9 \%$ $(\mathrm{n}=112 / 170)$ of patients in this study.

Frezza et al. ${ }^{14}$ in the group of liver transplant recipients treated with tacrolimus had a lower incidence of skin cancer than in the cyclosporine group. However, Jonas et al. ${ }^{13}$ found no difference between patients receiving cyclosporine and those receiving tacrolimus. In this study population, those who did not use tacrolimus in the first year after transplantation had a statistically significant chance of developing skin cancer $(p=0.0256)$ compared with those using this immunosuppressant.

Some studies have associated the increased incidence of post-transplant diabetes mellitus to the use of tacrolimus. ${ }^{15,16}$ Among the 16 patients studied that presented skin cancer, $25 \%$ (4/16) developed diabetes in the third year; of these, three received tacrolimus.

Presence of diabetes in $12.4 \%(21 / 170)$ of patients in the third year after the operation was also considered a risk factor $(p=0.0475)$ for skin cancer.

In some studies, increasing age was considered a risk factor for skin cancer, similar to what is observed in several neoplasms of other organs and in some studies in transplants. ${ }^{12-14}$ According to these studies, age greater than 40 years at the time of transplantation is a risk factor for the development of skin cancer. ${ }^{12}$ In our study population, age was not a significant factor.

Literature reports the increase in the frequency of skin cancer after kidney transplantation to smokers or history of smoking and alcohol consumption. ${ }^{17}$ In that study, in patients who presented alcoholic cirrhosis at the time of the operation $(p=0.075)$, those who were smokers or who had a smoking history (0.098) showed only a tendency to develop skin cancer, since the results were not significant.

As the medical records present information to obtain the MELD and BAR score and no information was found on the relation with skin cancer, it was decided to test this possibility. In this study population, there was no relation.

It is estimated that after a solid organ transplant there is a 
risk 3 to 4 times higher for CMM development, 10 times higher for BCC, approximately 20 times higher for Merkel cell carcinoma, 65 times higher for SCC and 84 times higher for Kaposi's sarcoma., ${ }^{8,18,19}$

Relation between SCC and BCC in kidney transplant recipients is inversely related to that of the general population, which was also observed in this study. ${ }^{17}$

Approximately $30 \%$ to $50 \%$ of patients who were treated with kidney and heart transplants and who developed SCC also developed BCC. ${ }^{20}$ In this study, $56.2 \%(9 / 16)$ of the patients presented more than one lesion, and $18.7 \%(3 / 16)$ of the patients who developed SCC presented BCC, a result that is lower than that found in the literature for kidney and heart transplant. ${ }^{20}$

We were surprised to find two patients with post-transplant $\mathrm{CMM}$. This incidence is higher than that found in the general population, since the gross CMM incidence rates, in the state of São Paulo, estimated in 2014, were 3.97 (men) and 4.59 (women) / $100000 .{ }^{21}$ It is a neoplasia with the potential to produce metastases and, therefore, of greater impact for the immunodeficient.

Photoexposed areas of transplanted patients with cutaneous neoplasias often have actinic damage. ${ }^{22}$ This actinic damage is translated by extensive pre-malignant lesions, such as actinic keratoses. Their presence is associated with a higher risk of non-melanoma skin cancer, as observed in our study $(\mathrm{OR}=22,300,95 \% \mathrm{CI}=$ $2,870-173,271, \mathrm{p}=0.003) .{ }^{23}$

Neoplasias tend to develop earlier and with more aggressive expression in transplanted patients than in immunocompetent individuals, which may lead to a $5 \%$ to $8 \%$ increase in transplanted patients mortality. ${ }^{8}$
Given the significant number of skin cancers in the populations of transplanted patients, the important morbidity and mortality associated with these diagnoses should not be neglected, which imposes their consideration as a public health problem, but with a feasible control by primary and secondary prevention..$^{24,25}$ After transplantation, the liver receptor should be accompanied by a multidisciplinary team and undergo evaluation by a dermatologist to recapitulate the actions for the early diagnosis, prevention and treatment of skin cancer. ${ }^{26}$

An important limitation of this study is that the interpretations of the results were based on information collected in patients undergoing transplantation in the same center. Future research, multicenter, both prospective and retrospective, are needed, involving larger and more diverse populations. Despite the methodological limitations of this type of study, these results point to the need to educate both patients and health professionals about skin cancer.

Risk factors found in this study may contribute to better monitoring in Brazilian surveillance programs and to the development of strategies associated with the reduction of the incidence of skin cancer in liver transplant patients.

\section{CONCLUSION}

Knowledge of the risk factors found in this study (diabetes in the third year after transplantation, not using tacrolimus in the first year after transplantation and actinic keratosis) may contribute to the development of specific strategies in Brazilian programs for the surveillance of skin cancer in patients treated with liver transplants. $\square$

\section{REFERENCES}

1. Manzoni AP, Kruse RL, Troian C, Cunha VS, Cestari TF. Skin changes in pediatric transplant patients. Pediatr Transplant. 2006;10:210-4.

2. Mithoefer AB, Supran S, Freeman RB. Risk factors associated with the development of skin cancer after liver transplantation. Liver Transpl. 2002;8:939-44.

3. Marqués Medina E, Jiménez Romero C, Gómez de la Cámara A, Rota Bernal A, Manrique Municio A, Moreno González E. Malignancy after liver transplantation: cumulative risk for development. Transplant Proc. 2009;41:2447-9.

4. Kullavanijaya P, Lim HW. Photoprotection. J Am Acad Dermatol. 2005;52:937-58.

5. Santos JO, Santos AR, Souza SO, Lima LL, Costa EF, Oliveira PTMS. Avaliação do nível de informação quanto à prevenção do câncer da pele em trabalhadores rurais do município de Lagarto, Sergipe. Resumos do II Congresso de Pesquisa e Inovação da Rede Norte Nordeste de Educação Tecnológica; 2007; 6p. João Pessoa; 2007.

6. Bouwes Bavinck JN, Hardie DR, Green A, Cutmore S, MacNaught A, O'Sullivan B, , et al. The risk of skin cancer in renal transplant recipients in Queensland, Australia. A follow-up study. Transplantation. 1996;61:715-21.

7. Winkelhorst JT, Brokelman WJ, Tiggeler RG, Wobbes T. Incidence and clinical course of de-novo malignancies in renal allograft recipients. Eur J Surg Oncol. 2001;27:409-13.
8. Euvrard S, Kanitakis J, Claudy A. Skin cancers after organ transplantation. N Engl J Med. 2003;348:1681-91.

9. Hartevelt MM, Bavinck JN, Kootte AM, Vermeer BJ, Vandenbroucke JP. Incidence of skin cancer after renal transplantation in The Netherlands. Transplantation. 1990;49:506-9.

10. Ulrich C, Schmook T, Sachse MM, Sterry W, Stockfleth E. Comparative epidemiology and pathogenic factors for nonmelanoma skin cancer in organ transplant patients. Dermatol Surg. 2004;30:622-7.

11. Broders C. Carcinoma in situ contrasted with benign penetrating epithelium. JAMA. 1932; 99:1670-7.

12. Alam M, Ratner D. Cutaneous squamous cell carcinoma. N Engl J Med. 2001;344:975-83

13. Jonas S, Rayes N, Neumann U, Neuhaus R, Bechstein WO, Guckelberger O, et al. De novo malignancies after liver transplantation using tacrolimus-based protocols or cyclosporine-based quadruple immunosuppression with an interleukin-2 receptor antibody or antithymocyte globulin. Cancer. 1997;80:1141-50.

14. Frezza EE, Fung JJ, van Thiel DH. Non-lymphoid cancer after liver transplantation. Hepatogastroenterology. 1997;44:1172-81.

15. Weir MR, Fink JC. Risk for posttransplant diabetes mellitus with current 
immunosuppressive medications. Am J Kidney Dis. 1999;34:1-13.

16. Reichart B, Meiser B, Viganò M, Rinaldi M, Yacoub M, Banner NR, et al. European multicenter tacrolimus heart pilot study: three year follow-up. J Heart Lung Transplant. 2001;20:249-250.

17. Ramsay HM, Fryer AA, Reece S, Smith AG, Harden PN. Clinical risk factors associated with nonmelanoma skin cancer in renal transplant recipients. Am J Kidney Dis. 2000;36:167-76.

18. Harwood CA, Proby CM, McGregor JM, Sheaff MT, Leigh IM, Cerio R. Clinicopathologic features of skin cancer in organ transplant recipients: A retrospective case-control series. J Am Acad Dermatol. 2006;54:290-300.

19. Moloney FJ, Comber H, O'Lorcain P, O'Kelly P, Conlon PJ, Murphy GM. A population-based study of skin cancer incidence and prevalence in renal transplant recipients. Br J Dermatol. 2006;154:498-504.

20. Euvrard S1, Kanitakis J, Pouteil-Noble C, Dureau G, Touraine JL, Faure M, et al. Comparative epidemiologic study of premalignant and malignant epithelial cutaneous lesions developing after kidney and heart transplantation. J Am Acad Dermatol. 1995;33:222-9.

21. Instituto Nacional de Câncer José Alencar Gomes da Silva. Estimativa 2014 Incidência de câncer no Brasil. [acesso em 10 de novembro de 2015]. Disponível em http://www.inca.gov.br/estimativa/2014/index.asp.

22. Ulrich C, Kanitakis J, Stockfleth E, Euvrard S. Skin Cancer in Organ Transplant Recipients - Where Do We Stand Today? Am J Transplant. 2008:8:2192-8.

23. Tessari G, Girolomoni G. Nonmelanoma skin cancer in solid organ transplan recipients: update on epidemiology, risk factors and management. Dermatol Surg. 2012:38:1622-30.

24. Fernandes S, Carrelha AS, Pinto GM, Nolasco F, Barroso E, Cardoso J. Patologia dermatológica em doentes transplantados hepáticos e renais referenciados à consulta de dermatologia e venereologia. Acta Med Port. 2013;26:555-63

25. Nora AB, Lovatto L, Panarotto D, Boniatti MM. Frequência de aconselhamento para prevenção de câncer da pele entre as diversas especialidades médicas em Caxias do Sul. An Bras Dermatol 2004; 79: 45- 51

26. Mendes KDS, Rossin FM, Ziviani LC, Ribeiro KP, Zago MMF, Ohler L, et al. Conhecimento de fatores de risco e medidas de foto proteção em receptores de transplante de fígado. J Bras Transpl. 2010; 13:1393-1448.
MAILING ADDRESS:

Gabriela Rached Campos

Cidade Universitária Zeferino Vaz, s/n

13.081-970 - Campinas, SP

Brazil

Email:gabriela_rached@yahoo.com.br

How to cite this article: Campos GR, Boin IFSF, Campos Junior ID, Cintra ML. Study of factors affecting the incidence of skin cancer in patients after liver transplant. An Bras Dermatol. 2017;92(4):492-8. 